\title{
SPIDER DIVERSITY (ARACHNIDA: ARANEAE) OF THE TEA PLANTATION AT SERANG VILLAGE, KARANGREJA SUB-DISTRICT, DISTRICT OF PURBALINGGA
}

\author{
GIANTI SIBARANI, IMAM WIDHIONO, DARSONO
}

Fakultas Biologi, Universitas Jenderal Soedirman, Jalan dr. Suparno 63 Purwokerto 53122

\section{A B S T R A C T}

Spiders are crucial in controlling insect pest population. The various cultivation managements such as fertilizer and pesticide application, weeding, pruning, harvesting, and cropping system affect their diversity. In the plantation, vegetation diversification has applied various practices, including monoculture, and intercropping, which influence the spider community. Thus, this study was intended to determine the spider abundance and diversity of the tea plantation, and the intercropping field (tea and strawberry) at Serang village, Karangreja Sub-District, District of Purbalingga. A survey and purposive sampling techniques were conducted, then the spiders were hand collected. Shannon-Wiener diversity (H'), Evenness (E), Simpson's dominance (D), and Sorensen's similarity (IS) indices were used to measure the spider diversity. The results revealed a total number of 575 individual spiders from 10 families, i.e., Araneae, Araneidae, Clubionidae, Linyphiidae, Lycosidae, Nephilidae, Oxyopidae, Salticidae, Tetragnathidae, Theridiidae, and Thomisidae. Araneidae was the most abundant in both fields. The total abundance of spiders in tea plantation (379 individuals), however, was greater than that in the intercropping field (196 individuals). Shannon-Wiener diversity reached $\mathrm{H}^{\prime}=1.873$ in the plantation, and $\mathrm{H}^{\prime}=1.975$ in the intercropping field.

KEY WORDS: diversity, Araneae, spider, plantation

Corresponding Author: IMAM WIDHIONO | email: imamwidhiono@yahoo.com

\section{N T RO D U C T IO N}

An agroecosystem is a man-modified ecosystem to produce desired crops. It provides a habitat for cultivated plants, wild plants, weeds, animals, and microbes. The habitat is grouped into the annual plant, and the seasonal plant habitats (Altieri \& Nicholls, 2004). The former might potentially increase spider population on a landscape scale, and spider abundance in cultivated fields (Schmidt \& Tscharntke, 2005).

Spiders are common in agroecosystem such as plantation. They contribute immensely to biodiversity in agroecosystem and play a major role as an effective component of natural pest control (Symondson et al., 2002). Various cultivation activities such as fertilizer and pesticide application, weeding, pruning, harvest, and crop systems, performed by the human in plantation fields, affect the spider community (Altieri \& Nicholls, 2004). Intensive management for better crop production involving the use of synthetic pesticides and inorganic fertilizers has raised concerns in reduced diversity and abundance of arthropods, including spiders (Thomas \& Marshall, 1999). Nevertheless, cropping systems with conservation techniques might stimulate predatory arthropods diversity and abundance (Altieri \& Nicholls, 2004).

Diversification of vegetation in plantation involves various practices, such as monoculture and intercropping, which affect the spider diversity and abundance (Andow, 1991). According to Russell (1989), intercropping provides more niches than monoculture, thereby, increasing the spider diversity and abundance, the natural enemies of the pest.
Serang village belongs to the typology of NearForest Village in the area of Karangreja Sub-District, District of Purbalingga, Province of Central Java. The village is on the Mount Slamet slope which has rich soil spreading across 2,096.916 Ha. This area mostly is agricultural (strawberry cultivation) or plantation (tea) fields (Sugito, 2016).

Tea plantation is a stable and complex ecosystem which provides a habitat for many species of spiders that play a role in controlling insect pest population of tea plant (Das et al., 2010; Yan et al., 1998). However, plant cultivation practices may decrease their diversity and abundance (Thomas \& Marshall, 1999). Biological control refers to natural biotic management and regulation of insect pest suppression below economic injury level (Hazarika et al., 2001). Understanding the spider community within plant scope is important to improve pest control, and comprehend the compelling factors affecting conservation strategy (Raychaudhuri, 2016).

This study was aimed to investigate the spider abundance and diversity in tea plantation and intercropping field (tea and strawberry) in Serang Village, Karangreja Sub-District, District of Purbalingga. The scientific information of this study was expected to contribute to spider diversity knowledge in plantation field and to highlight the importance of spiders as a biological control agent.

\section{MET H O DS}

Materials included spiders and $70 \%$ alcohol, and the tools were specimen jars, measuring tape, plastic string, stationery, stereo microscope, petri dish, camera, and selfadhesive labels. 
The research was conducted in tea plantation and intercropping field (tea and strawberry) in Serang Village, Karangreja Sub-District, District of Purbalingga for four months, from April to July 2016. The samples, using purposive sampling technique, were collected from two cropping systems of tea, i.e. monoculture and intercropping. The spiders were handpicked from nine plots of $3 \times 3 \mathrm{~m}$ on both the tea plantation and intercropping field each having an area of $30 \times 30 \mathrm{~m}$. Samples were obtained between 07.00 am and $05.00 \mathrm{pm}$ Western Indonesian Time, with four replicates at a one-week interval.

The observed variable was the spider community. Measured parameters included the number of spider species and individuals. Each collected spiders was stored in a labeled specimen jar containing $70 \%$ alcohol. The label recorded the collection date, replicate, and plot number. Spiders with different morphological characteristics were collected separately to further identified and labeled according to alphabetical code to differentiate them.

Spider identification was performed in Entomology and Parasitology Laboratory, Faculty of Biology, Universitas Jenderal Soedirman based on morphological characteristics according to Barrion \& Litsinger (1995) and Hawkeswood (2003). Morphological characters observed were the spider eye arrangement and position, tarsus setae, femur and tarsus spines, palpus shape and size, abdomen shape and size.

Spider diversity was analyzed by measuring diversity, evenness, and similarity indices with PAST 3 software. Shannon-Wiener diversity index was used to measure diversity following this formula (Magurran, 2004):

$$
H^{\prime}=-\sum_{i=1}^{s} p i \ln p i
$$

Where,

$\mathrm{H}^{\prime}=$ Shannon-Wiener diversity index

$p i=$ Total individual(s) found within species $\mathrm{i}$

$$
E=\frac{H^{\prime}}{\ln S}
$$

Where,

$\mathrm{E}=$ Evenness index

$\mathrm{H}^{\prime}=$ Shannon-Wiener diversity index

$\mathrm{S}=$ Total species of spider

Simpson's dominance index was used to measure dominance following this formula (Magurran, 2004):

$$
\mathrm{D}=\sum(p i)^{2}=\sum\left(\frac{n i}{N}\right)^{2}
$$

Where,

$\mathrm{D}$ =Simpson's dominance index

ni $=$ total individuals within a species

$\mathrm{N}$ =total individuals within all species

Sorensen's similarity index was used to determine communities of two different sites (Magurran, 2004):

$$
\text { IS }=\frac{2 c}{a+b} \times 100 \%
$$

Where,

IS = Sorensen's similarity index

$\mathrm{a} \quad=$ Total species of spiders found in site $\mathrm{a}$

b = Total species of spiders found in site $b$

$\mathrm{c} \quad=$ Total same species of spiders found in site $\mathrm{a}$ and $\mathrm{b}$

\section{RESULTS AND DISCUSSION}

There was a total of 575 individual spiders observed from tea plantation and intercropping field belonging to 10 families. Most families (6) including Clubionidae, Linyphiidae, Theridiidae, Thomisidae, Nephilidae, and Oxyopidae consisted of one morphospecies each. Two morphospecies were observed each in Lycosidae and Tetragnathidae. Araneidae had five morphospecies whereas the most diverse morphospecies was observed in Salticidae (8) (Table 1).

Compared to the intercropping field, the spider abundance was higher on the tea plantation, to which this contributed to $65.91 \%$ of the total spider collected (379 individuals). In the intercropping field, it reached 196 individuals (34,09\%) (Table 1). The difference most likely was caused by different crop practices and management of each area which in turn affected spider abundance. The tea plantation was a monoculture field that created a favorable environment for insect pests thus stimulated their populations to increase as the spider available food. As a result, this condition might promote spider abundance. Aswad (2014) reported that monoculture plantation field could cause pest outbreak or an increase in particular insect pest population which results in the growth of spider population as their natural enemy.

Tea plantation of the study site was less managed than in the intercropping field, thus influenced spider abundance. In the intercropping field, crop intensification (regular weeding) was applied, while in tea plantation this was done irregularly. Altieri\& Schmidt (1986) claimed that habitat with intensive soil management showed low numbers of individual spiders. Araneidae was the most spider family observed in either tea plantation (69.13\%) or intercropping field (Figure 1).

In the intercropping field, 196 individual spiders were recorded, and 142 of them $(72.45 \%)$ belonged to Araneidae. According to Riechert\& Lockley (1984), Araneidae was a spider family distributed worldwide and able to live in various habitats by creating circular and sticky web traps. Araneidae was one of the most successful families within order Araneae (approximately 2,600 species). This group of spiders was easy to identify due to their body size, body coloration, and net shape or pattern (JimenezValverde \& Lobo, 2007).

Clubionidae within order Araneae was the rarest family (one individual, $0.17 \%$ ). According to Riechert \& Lockley (1984), worldwide distribution members of Clubionidae lived freely as nocturnal hunters and usually place their sac-like traps in plant leaves. Spiders from genus Clubiona moved on plant stems and leaves at night. During the daytime, they hid in silk sacs made of grass leaf folds or other similar leaves. Members of this genus had small to medium body size. The abdomen was covered with pale yellow hair, and their mouth was often brown in color (Dippenaar-Schoeman, 1988). 
Table 1. Total Number and Proportion of Spiders in Tea Plantation and Intercropping Field

\begin{tabular}{|c|c|c|c|c|c|c|}
\hline \multirow{3}{*}{ Family } & \multirow{3}{*}{ Morphospecies } & \multicolumn{4}{|c|}{ Type of habitat } & \multirow{3}{*}{ Total } \\
\hline & & \multicolumn{2}{|c|}{ Tea plantation } & \multicolumn{2}{|c|}{ Intercropping field } & \\
\hline & & $\begin{array}{r}\text { Number of } \\
\text { individual(s) }\end{array}$ & $\begin{array}{r}\text { Proportion } \\
(\%)\end{array}$ & $\begin{array}{r}\text { Number of } \\
\text { individual(s) }\end{array}$ & $\begin{array}{r}\text { Proportion } \\
(\%)\end{array}$ & \\
\hline \multirow[t]{5}{*}{ Araneidae } & Argiope spp1. & 5 & 1.32 & 9 & 4.59 & 14 \\
\hline & Argiope spp2. & 1 & 0.26 & 0 & 0 & 1 \\
\hline & Cyclosa spp1. & 88 & 23.22 & 58 & 29.59 & 350 \\
\hline & Cyclosa spp2. & 30 & 7.92 & 14 & 7.14 & 39 \\
\hline & Cyclosa spp3. & 138 & 36.41 & 61 & 3112 & \\
\hline Clubionidae & Clubiona spp. & 0 & 0 & 1 & 0.51 & 1 \\
\hline Linyphiidae & Erigoninae spp. & 10 & 2.64 & 9 & 4.59 & 19 \\
\hline \multirow[t]{2}{*}{ Lycosida } & Pardosa spp1. & 1 & 0.26 & 1 & 0.51 & 2 \\
\hline & Pardosa spp2. & 4 & 1.06 & 4 & 2.04 & 8 \\
\hline Nephilidae & Nephila spp. & 3 & 0.79 & 0 & 0 & 3 \\
\hline Oxyopidae & Oxyopes spp. & 8 & 2.11 & 5 & 2.55 & 13 \\
\hline \multirow[t]{8}{*}{ Salticidae } & Bianor spp. & 2 & 0.53 & & & \\
\hline & Chalcotropis spp. & 0 & 0 & 2 & 1.02 & 1 \\
\hline & Cosmophasis spp1. & 3 & 0.79 & 0 & 0 & 4 \\
\hline & Cosmophasis spp2. & 2 & 0.53 & 1 & 0.51 & 2 \\
\hline & Emathis spp. & 4 & 1.06 & 1 & 0.51 & \\
\hline & Harmochirus spp. & 3 & 0.79 & 0 & 0 & 4 \\
\hline & Hasarius spp. & 2 & 0.53 & 2 & 1.02 & 10 \\
\hline & Palpelius spp. & 2 & 0.53 & 1 & 0.51 & 3 \\
\hline \multirow[t]{2}{*}{ Tetragnathidae } & Leucauge spp. & 66 & 17.41 & 23 & 11.73 & 86 \\
\hline & Tetragnatha spp. & 7 & 1.85 & 2 & 1.02 & 7 \\
\hline Theridiidae & Cryptachaea spp. & 0 & 0 & 3 & 1.53 & 5 \\
\hline Thomisidae & Cerinius spp. & 0 & 0 & 1 & 0.51 & 1 \\
\hline \multicolumn{2}{|c|}{ Number of individuals } & 379 & 100 & 196 & 100 & 575 \\
\hline \multicolumn{2}{|c|}{ Number of morphospecies } & 19 & & 18 & & 23 \\
\hline \multicolumn{2}{|c|}{ Number of families } & 8 & & 9 & & 10 \\
\hline \multicolumn{2}{|c|}{ Total proportion } & $65.91 \%$ & & $34.09 \%$ & & $100 \%$ \\
\hline
\end{tabular}

Besides Clubionidae, Thomisidae was also among the rarest families to find $(0,17 \%)$. This might be because members of this family mostly created webs in flowers and only a small number of flowers grew in both study sites. According to Jimenez-Valverde and Lobo (2007), spiders of Thomisidae had crab-like body shape and often hid in flowers and had cryptic coloration.

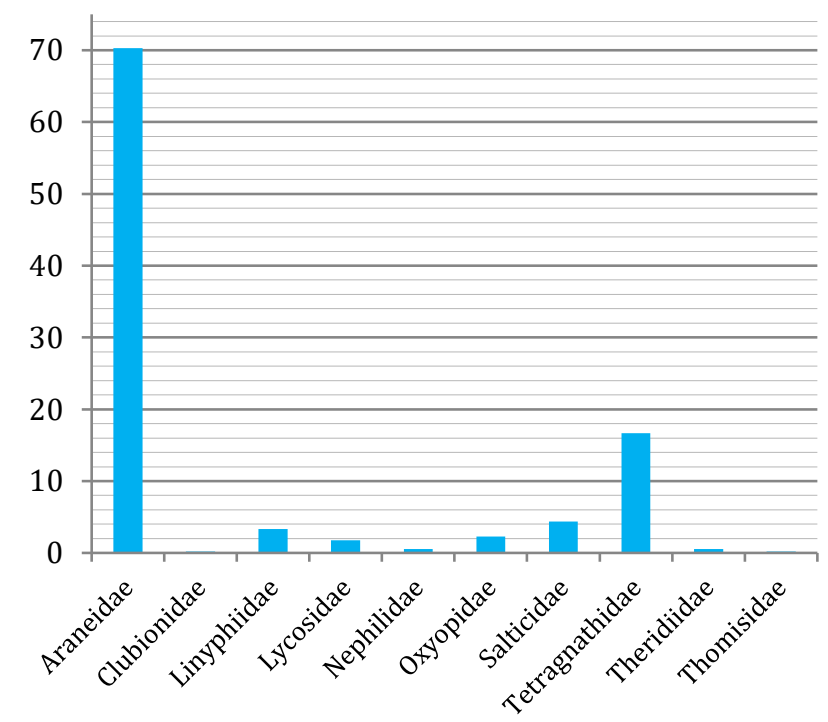

Figure1. Abundance Proportion of Spider Families in Tea Plantation and Intercropping Fields in Serang Village, District of Purbalingga
The tea plantation and intercropping fields showed different diversity indices (Table 2). The indices of tea plantation reached $\mathrm{H}^{\prime}=1.873$, and the intercropping field was $\mathrm{H}^{\prime}=1.975$. This difference indicated that spiders in the intercropping field were more diverse than those in tea plantation. According to Russell (1989), intercropping fields provided more niches than monoculture fields. Thus, the diversity of natural enemies including spiders was also high.

Table 2. Diversity, Evenness, and Similarity Indices of Spiders in Tea Plantation and Intercropping Field

\begin{tabular}{|c|c|c|}
\hline Parameter & Tea Plantation & Intercropping Field \\
\hline $\mathrm{H}^{\prime}$ & 1.873 & 1.975 \\
\hline $\mathbf{E}$ & 0.343 & 0.399 \\
\hline IS & \multicolumn{2}{|c|}{$75.68 \%$} \\
\hline
\end{tabular}

Tea plantation showed lower evenness index than the intercropping field (Table 2). According to Brower et al. (1998), evenness level was considered low if it was less than 0.4 , medium if between 0.4 and 0.6 , high when it was greater than 0.6. Spider evenness indices in both study sites were from 0.343 up to 0.399 . This range indicated low spider evenness level in both tea plantation and intercropping fields. Suana (2005) stated that evenness index tends to be low when there were one or few dominant species in the sample, and other species of the same sample were in small number. 
Sorensen's similarity index revealed species similarity level in two different sites. Similarity index of spiders in tea plantation and the intercropping fields was 75.68\% (Table 2). According to Brower et al. (1998), a similarity index of $25 \%$ or lower indicated strong dissimilarity, $25-50 \%$ showed no similarity between two sites, and an index of $50 \%$ or greater was strongly similar. The index indicated that tea plantation and intercropping field had strong spider species similarity. This criterion was based on Suin (1991) who claimed that two ecosystems were considered to have a similar community if their similarity index was greater than 50\%. The macroarthropods similarity of two communities, such as spiders, might be due to the adjacent fields which allowed spiders to move actively from one location to other nearby locations.

\section{O N C L USIO N}

A total of 379 individual spiders was recorded from tea plantation with diversity index $\mathrm{H}^{\prime}$ of 1.975 , higher than that of intercropping field $\left(\mathrm{H}^{\prime}=1.873 ; 196\right.$ individuals). The evenness in tea plantation and intercropping field were low with a range from 0.343 up to 0.399 . Araneae community in tea plantation and intercropping field revealed a similarity of $75.68 \%$ by Sorensen's similarity index.

\section{RE FE R E N C ES}

Altieri MA, Nicholls CI. 2004. Biodiversity and pest management in agroecosystems. $2^{\text {nd }}$ ed. New York:An Imprint of The Haworth Press Inc.

Altieri MA, Schmidt LL. 1986. Cover crops affect insect and spider populations in apple orchards. California Agriculture, pp:15-17

Andow DA. 1991. Yield Loss to Arthropods in Vegetationally Diverse Agroecosystems. Environmental Entomolology 20(5):1228-1235

AswadM, Koneri R, Siahaan P. 2014. KomunitasLaba-laba (Arachnida:Araneae) padaLahan Perkebunan di Kawasan Taman NasionalBoganiNaniWartabone Sulawesi Utara. Jurnal MIPA UNSRAT Online 3(2):64-67

Barrion AT, Litsinger JA. 1995. Riceland spiders of South and Southeast Asia. Wallingford:CAB International; Manila:Int. Rice Res. Inst.

Brower JE, Jerrold CHZ, Von EIN. 1998. Field and Laboratory Methods for General Ecology, Third Edition. New York:Wm,C,Brown Publisher
Das S, Roy S, Mukhopadhyay A. 2010. Diversity of arthropod natural enemies in the tea plantations of North Bengal with emphasis on their association with tea pests. Current Science 99(10):1457-1463

Dippenaar-Schoeman AS. 1988. Annoted Check List of the Spiders (Araneae) of the Mountain Zebra National Park.Koedoe 31:151160

Hawkeswood T. 2003. Spiders of Australia:an introduction to their classification, biology and distribution. Moscow, Russia:Pensoft.

Hazarika LK, Puzari KC, Wahab S. 2001. Biological Control of Tea Pests.In Biocontrol Potential and Its Exploitation in Sustainable Agriculture. Vol. 2:Insect Pests, ed. RK Upadhyay, KG Mukerji, BP Chamola, pp:159-80. New York:Kluwer Academic 421p.

Jimenez-Valverde A,Lobo JM. 2007. Determinants of local spider (Araneidae and Thomisidae) species richness on a regional scale:climate and altitude vs. habitat structure. Ecological Entomology 32:113-122

Magurran AE. 2004. Measuring Biological Diversity. USA:Blackwell Publishing Company.

Raychaudhuri D, Saha S, Roy TK. 2016. Spiders:A Proficient Candidate in Practising IPM for Darjeeling Tea. World Scientific News 38:1-62

Riechert SE, Lockley T. 1984. Spiders as biological control agents.Annu. Rev. Entomol. 29:229-320

Russell EP. 1989. Enemies Hypothesis:A Review of the Effect of Vegetational Diversity on Predatory Insects and Parasitoids. Environmental Entomology 18(4):590-599

Schmidt MH,Tscharntke T. 2005. The role of perennial for Central European farmland spiders. Agriculture, Ecosystems and Environment 105:235-242

Suana IW, Solibin DD, Buchori D, Manuwoto S, Triwidodo H. 2005. KolonisasidanSuksesiLaba-laba padaPertanamanPadi.JurnalBiologi 9(1):1-7

(Araneae)

Sugito.2016. PaparanKegiatanPemerintahandan Pembangunan DesaSerang.wawancara. SerangKarangrejaPurbalingga.

Suin NM.1991. PerbandinganKomunitasHewanPermukaan Tanah antaraLadangdanHutan di Bukit Pinang-Pinang Padang.LaporanPenelitianUniversitasAndalas.

Padang:UniversitasAndalas

Symondson WOC, Sunderland KD, Greenstone MH. 2002. Can generalist predators be effective biocontrol agents? Annu. Rev. Entomol. 47:561-594

Thomas CFG, Marshall EJP. 1999. Arthropod abundance and diversity in differently vegetated margins of arable fields. Agriculture, Ecosystem and Environment 72:131-144

Yan HM, Liu MY,Kim JP. 1998. Predation Efficiency of the Spider Tetragnathasquamata (Araneae:Tetragnathidae) to Tea Leafhopper Empoascavitis (Insecta:Homoptera). The Korean Journal of Systematic Zoology 14(2):159-164 